Acta Crystallographica Section E

Structure Reports

Online

ISSN 1600-5368

M Mahendra, ${ }^{a}$ K. Jayalakshmi, Basappa, ${ }^{\text {b }}$ K. S. Rangappa, ${ }^{b}$

M. A. Sridhar ${ }^{\mathrm{a}}$ and

J. Shashidhara Prasad ${ }^{\mathrm{a} *}$

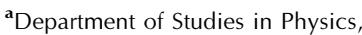

Mansagangotri, University of Mysore, Mysore 570 006, India, and ${ }^{\mathbf{b}}$ Department of Studies in Chemistry, Manasagangotri, University of Mysore, Mysore 570 006, India

Correspondence e-mail:

mas@physics.uni-mysore.ac.in

\section{Key indicators}

Single-crystal X-ray study

$T=293 \mathrm{~K}$

Mean $\sigma(\mathrm{C}-\mathrm{C})=0.003 \AA$

$R$ factor $=0.045$

$w R$ factor $=0.110$

Data-to-parameter ratio $=23.8$

For details of how these key indicators were automatically derived from the article, see http://journals.iucr.org/e.

\title{
2-(Biphenyl-4-yl)-3-(4-methoxyphenyl)- 1,3-thiazolidin-4-one
}

In the title molecule, $\mathrm{C}_{22} \mathrm{H}_{19} \mathrm{NO}_{2} \mathrm{~S}$, the thiazolidinone ring exhibits a flattened envelope conformation. The methoxyphenyl and biphenyl substituents are in pseudo-equatorial and pseudo-axial orientations, respectively, with respect to the thiazolidinone ring.

\section{Comment}

The thiazolidin-4-one ring system exists in a number of biologically active compounds which exhibit anticonvulsant (Ragab et al., 1997), hypnotic (Chaudhary et al., 1975), antiinflammatory (Vigorita et al., 2001), antiproteolytic (Chaudhari et al., 1976) and antituberculous (Babaoglu et al., 2003) properties. The usual conformations of the thiazolidin-4-one ring are envelope or half-chair (Diurno et al., 1992). The structural and conformational features of thiazolidin-4-one derivatives are essential in the study of their structure-activity relationships. As part of our continuing research in the synthesis of nitrogen-containing biologically active heterocyclic compounds (Ravikumar et al., 2003; Basappa et al., 2003), the title compound, (I) (Fig. 1), has been synthesized and we present its crystal structure here.

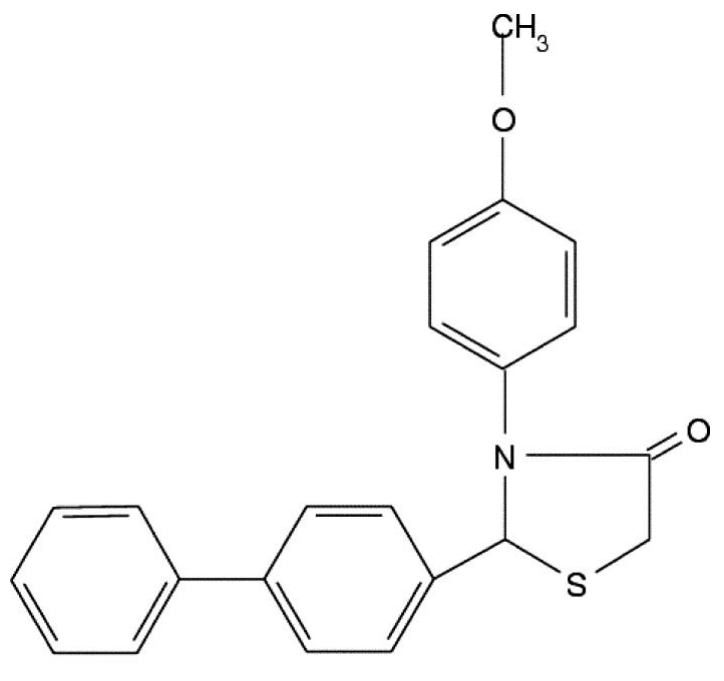

(I)

The thiazolidinone ring in (I) exhibits a flattened envelope conformation, where atom S14 is displaced by 0.3918 (8) $\AA$ from the mean plane of atoms C15/C16/N18/C13. This conformation may be caused by the different steric hindrance of the substituents attached to atoms N18 and C13. These substituents, viz. methoxyphenyl and biphenyl, respectively, show pseudo-equatorial and pseudo-axial orientations, respectively, with respect to the thiazolidinone ring. Most of
Received 6 June 2005 Accepted 22 June 2005 Online 30 June 2005 


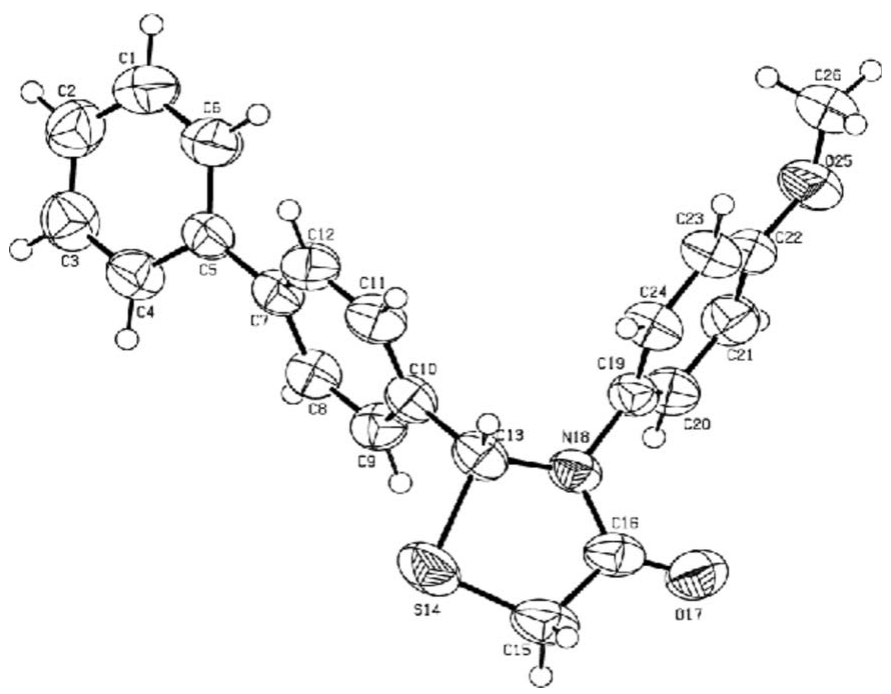

Figure 1

View of (I), with $50 \%$ probability displacement ellipsoids.

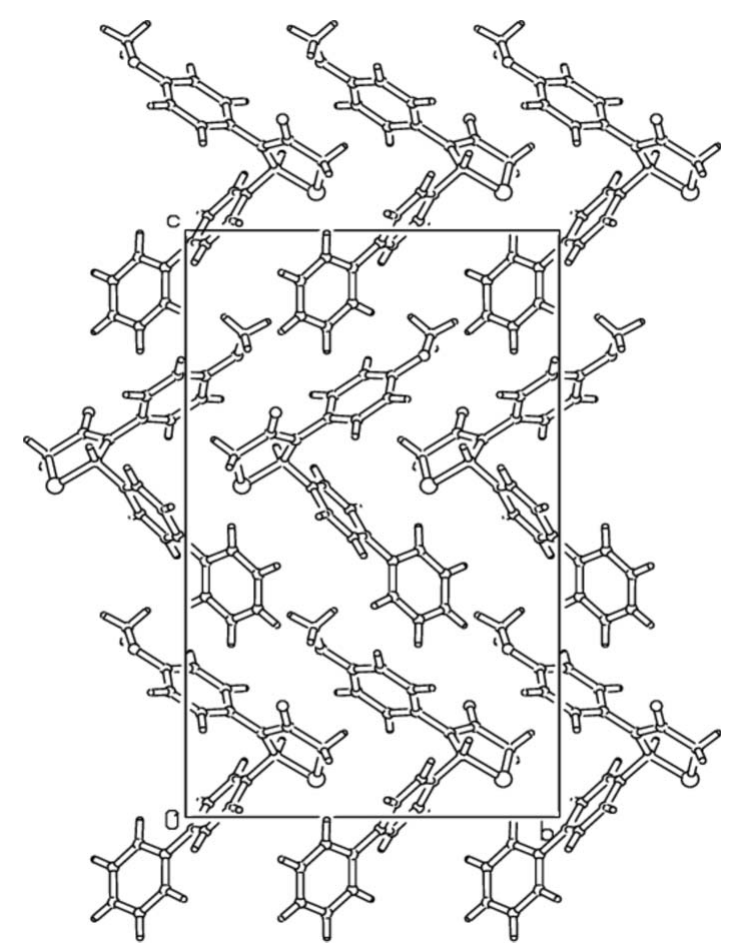

Figure 2

The crystal packing in (I), viewed down the $a$ axis.

the bond lengths and angles (Table 1) have normal values. The crystal packing (Fig. 2) is stabilized by van der Waals forces.

A detailed study of the biological activity of (I) is underway.

\section{Experimental}

4-Methoxyaniline (5 g, $1 \mathrm{~mol})$, 4-biphenylcarboxaldehyde (7.39 g, $1.0 \mathrm{~mol})$ and anhydrous $\gamma$-ferrite $(12.96 \mathrm{~g}, 2 \mathrm{~mol})$ were refluxed with constant stirring in dry benzene for $30 \mathrm{~min}$, after which thioglycolic acid $(2.82 \mathrm{ml}, 1 \mathrm{~mol})$ was added to the reaction mixture. Reflux and

stirring were continued for another $3 \mathrm{~h}$. The reaction was monitored by thin-layer chromatography $\left(R_{\mathrm{F}}=0.56\right)$. After completion of the reaction, a red-brown amorphous solid, $\mathrm{Fe}_{2} \mathrm{O}_{3} \cdot 2 \mathrm{H}_{2} \mathrm{O} / \mathrm{FeO}(\mathrm{OH})$, was removed by filtration. The filtrate was concentrated to dryness under reduced pressure. The product was confirmed by spectroscopic characterization (yield $78^{\circ}$, m.p. 415-417 K). Anaylsis calculated: C 73.10, H 5.29, N 3.87, S 8.87\%; found: C 73.17, H 5.22, N 3.89, $\mathrm{S} 8.86 \% .1 \mathrm{~g}$ of (I) was taken up in $15 \mathrm{ml}$ of methanol. Charcoal $(1 \mathrm{~g})$ was added and the solution was heated for 2 to $3 \mathrm{~min}$. The hot solution was filtered through a Whatmann 42 filter paper. The solution was kept in a slightly opened conical flask. Crystals were obtained after a few days.

\section{Crystal data}

\section{$\mathrm{C}_{22} \mathrm{H}_{19} \mathrm{NO}_{2} \mathrm{~S}$ \\ $M_{r}=361.44$ \\ Orthorhombic, $P b c 2_{1}$ \\ $a=6.287(5) \AA$ \\ $b=13.248(9) \AA$ \\ $c=22.250(9) \AA$ \\ $V=1853.2(2) \AA^{3}$ \\ $Z=4$ \\ $D_{x}=1.295 \mathrm{Mg} \mathrm{m}^{-3}$}

\section{Data collection}

DIPLabo 32001 diffractometer

$\omega$ scans

5948 measured reflections

5640 independent reflections

4167 reflections with $I>2 \sigma(I)$

\section{Refinement}

Refinement on $F^{2}$

$R\left[F^{2}>2 \sigma\left(F^{2}\right)\right]=0.045$

$w R\left(F^{2}\right)=0.110$

$S=1.09$

5640 reflections

237 parameters

$\mathrm{H}$-atom parameters constrained

$w=1 /\left[\sigma^{2}\left(F_{\mathrm{o}}^{2}\right)+(0.0375 P)^{2}\right.$

$+0.2616 P]$

where $P=\left(F_{\mathrm{o}}{ }^{2}+2 F_{\mathrm{c}}{ }^{2}\right) / 3$

Table 1

Selected geometric parameters $\left(\AA{ }^{\circ}\right)$.

\begin{tabular}{llll}
\hline S14-C13 & $1.8261(19)$ & $\mathrm{O} 25-\mathrm{C} 26$ & $1.413(4)$ \\
S14-C15 & $1.778(3)$ & $\mathrm{N} 18-\mathrm{C} 13$ & $1.465(2)$ \\
$\mathrm{O} 17-\mathrm{C} 16$ & $1.222(2)$ & $\mathrm{N} 18-\mathrm{C} 16$ & $1.355(2)$ \\
$\mathrm{O} 25-\mathrm{C} 22$ & $1.367(3)$ & $\mathrm{N} 18-\mathrm{C} 19$ & $1.442(2)$ \\
& & & \\
$\mathrm{C} 13-\mathrm{S} 14-\mathrm{C} 15$ & $92.75(10)$ & $\mathrm{S} 14-\mathrm{C} 15-\mathrm{C} 16$ & $108.15(15)$ \\
$\mathrm{C} 22-\mathrm{O} 25-\mathrm{C} 26$ & $118.21(19)$ & $\mathrm{O} 17-\mathrm{C} 16-\mathrm{N} 18$ & $124.48(17)$ \\
$\mathrm{C} 13-\mathrm{N} 18-\mathrm{C} 16$ & $117.21(15)$ & $\mathrm{O} 17-\mathrm{C} 16-\mathrm{C} 15$ & $123.18(18)$ \\
$\mathrm{C} 13-\mathrm{N} 18-\mathrm{C} 19$ & $119.77(14)$ & $\mathrm{N} 18-\mathrm{C} 16-\mathrm{C} 15$ & $112.33(17)$ \\
$\mathrm{C} 16-\mathrm{N} 18-\mathrm{C} 19$ & $120.82(15)$ & $\mathrm{N} 18-\mathrm{C} 19-\mathrm{C} 20$ & $119.71(16)$ \\
S14-C13-N18 & $105.11(12)$ & $\mathrm{N} 18-\mathrm{C} 19-\mathrm{C} 24$ & $120.52(16)$ \\
S14-C13-C10 & $109.94(14)$ & $\mathrm{O} 25-\mathrm{C} 22-\mathrm{C} 21$ & $115.40(18)$ \\
$\mathrm{N} 18-\mathrm{C} 13-\mathrm{C} 10$ & $114.27(14)$ & $\mathrm{O} 25-\mathrm{C} 22-\mathrm{C} 23$ & $124.62(19)$ \\
\hline
\end{tabular}

The $\mathrm{H}$ atoms were placed at idealized positions and allowed to ride at the parent $\mathrm{C}$ atoms, with $\mathrm{C}-\mathrm{H}=0.96 \AA$ and $U_{\text {iso }}(\mathrm{H})=1.2 U_{\text {eq }}(\mathrm{C})$. The value of the Flack parameter (Flack, 1983) indicates an inversion twin. $P b c 2_{1}$ is a unconventional setting of $P c a 2_{1}$. Since the transformation to the conventional setting did not yield a better solution, $\mathrm{Pbc} 21$ was retained. 
Data collection: XPRESS (MacScience, 2002); cell refinement: SCALEPACK (Otwinowski \& Minor, 1997); data reduction: DENZO (Otwinowski \& Minor, 1997) and SCALEPACK; program(s) used to solve structure: SHELXS97 (Sheldrick, 1997); program(s) used to refine structure: SHELXL97 (Sheldrick, 1997); molecular graphics: PLATON (Spek, 2003); software used to prepare material for publication: SHELXL97.

We thank the DST, Government of India, for financial assistance under project No. SP/I2/FOO/93. MM thanks the CSIR, Government of India, for the award of a Senior Research Fellowship.

\section{References}

Babaoglu, K., Page, M. A., Jones, V. C., McNeil, M. R., Dong, C., Naismith, J. H. \& Lee, R. E. (2003). Bioorg. Med. Chem. Lett. 13, 3227-3230.
Basappa, Sadashiva, M. P., Mantelingu, K., Swamy, N. S. \& Rangappa, K. S. (2003). Bioorg. Med. Chem. 11, 4539-4544.

Chaudhari, A., Kumar, S., Singh, S. P., Parmar, S. S. \& Stenberg, V. I. (1976). J. Pharm. Sci. 65, 758-761.

Chaudhary, S. K., Verma, M., Chaturvedi, A. K. \& Parmar, S. S. (1975). J. Pharm. Sci. 64, 615-617.

Diurno, M., Mazzoni, O., Piscopo, E., Calignano, A., Giordano, F. \& Bolognese, A. (1992). J. Med. Chem. 35, 2910-2912.

Flack, H. D. (1983). Acta Cryst. A39, 876-881.

MacScience (2002). XPRESS. MacScience Co. Ltd, Yokohama, Japan.

Otwinowski, Z. \& Minor, W. (1997). Methods in Enzymology, Vol. 276, Macromolecular Crystallography, Part A, edited by C. W. Carter Jr \& R. M. Sweet, pp. 307-326. New York: Academic Press.

Ragab, F. A., Eid, N. M. \& El-Tawab, H. A. (1997). Pharmazie, 52, 926-929.

Ravikumar, K. R., Mallesh, H., Basappa \& Rangappa, K. S. (2003). Eur. J. Med. Chem. 38, 613-619.

Vigorita, M. G., Ottana, R., Monforte, F., Maccari, R., Trovato, A., Monforte, M. T. \& Toviano, M. F. (2001). Bioorg. Med. Chem. Lett. 11, 2791-2794.

Sheldrick, G. M. (1997). SHELXS97 and SHELXL97. University of Göttingen, Germany.

Spek, A. L. (2003). J. Appl. Cryst. 36, 7-13. 